\title{
膀脱壁二及ボス直電流了影響竡二 $\mathrm{NaCl}, \mathrm{KCl}, \mathrm{CaCl}_{2}$ 卜ノ共同作用二就 テ
}

\author{
岡山㗨科大眾解剖學致空 (主任上坂教授)
}

岡島䶀

(本諭文要旨一昭和 3 年度第 36 回日本解剖學曾繶曾始=

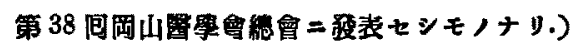

\section{第 1 章 緒 雫}

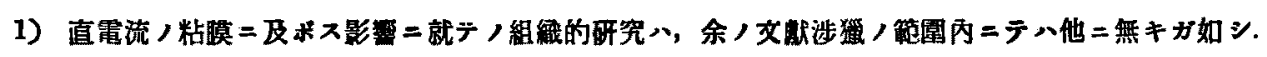

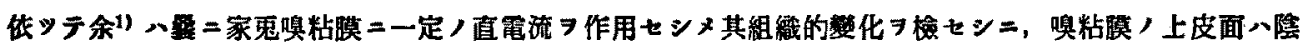

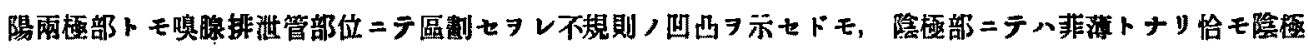

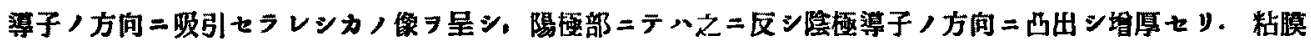

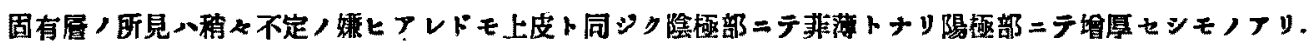

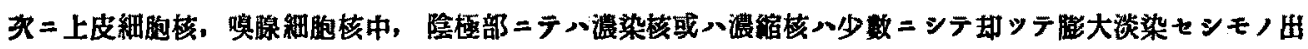

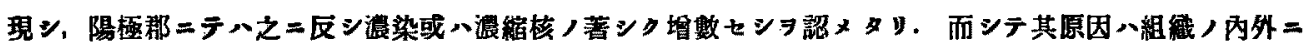

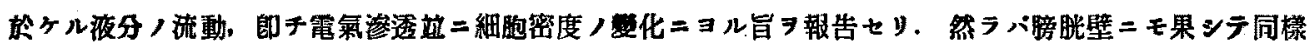
，所見习証メ得ルヤ否ヤ，是レ本研究ヨ企テシ理由ノ1ナリ.

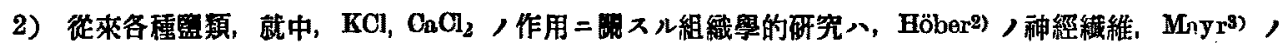

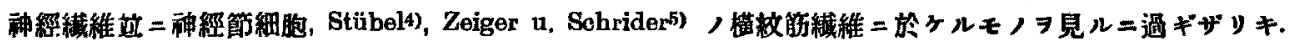

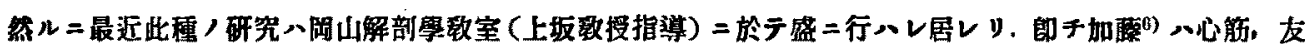

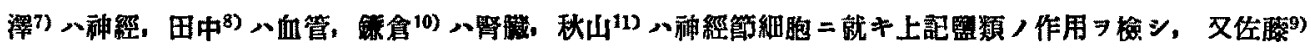

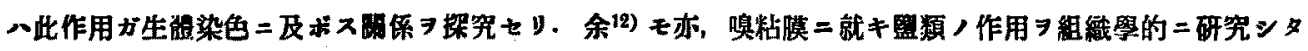

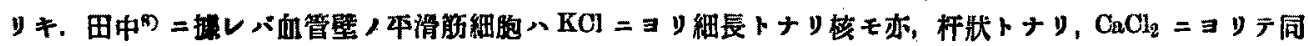

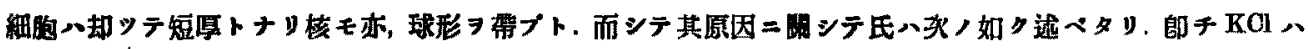

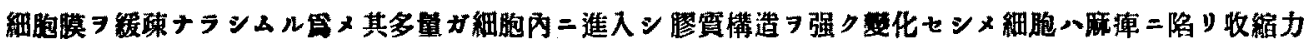

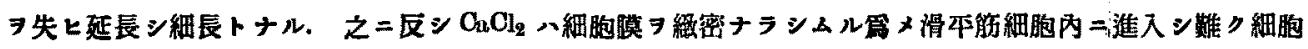

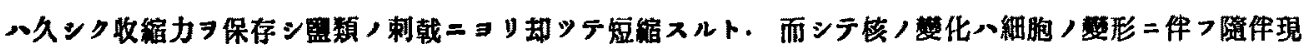
象ナリト君ーリ。

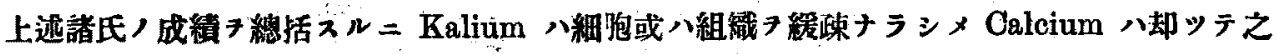

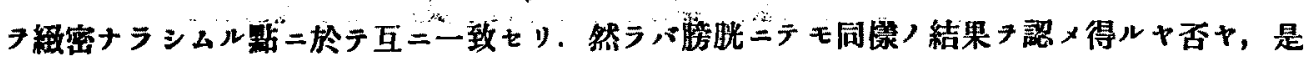
レ本确究 $フ$ 企テシ理由ノ 2 ナリ.

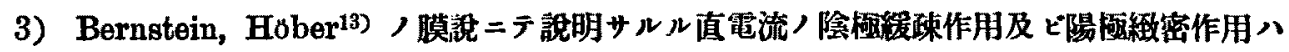




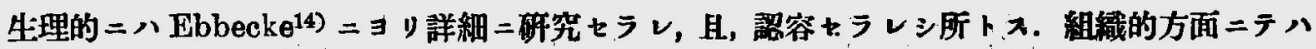

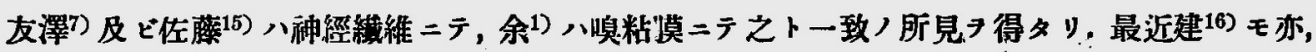

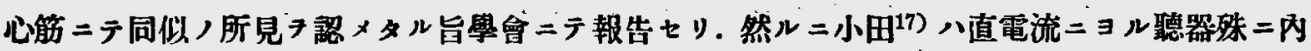

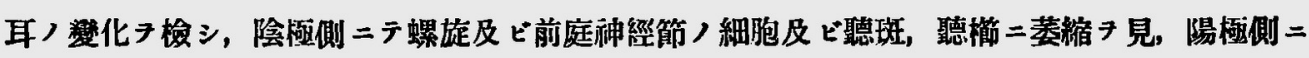
テハ之二反シ其腫脹タ認メタッ．然レドモ氏ハコハ水分／流動ニヨル二次的變化ニシテ一次的

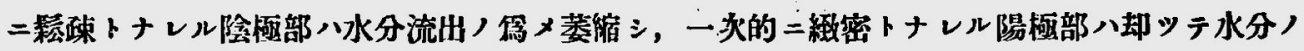

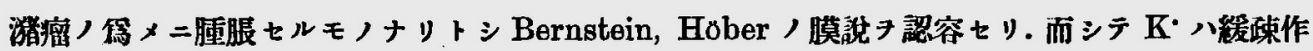

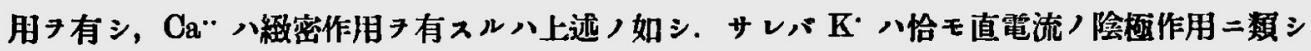

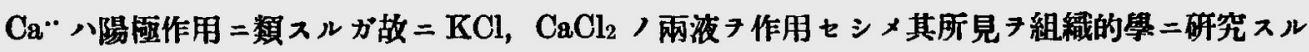

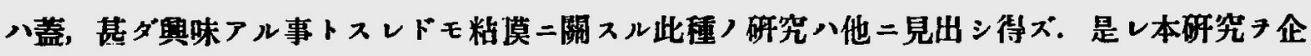

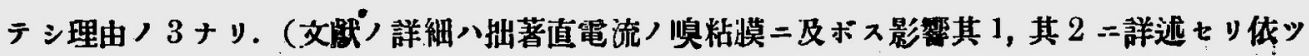
テ本綆ニテハ之ョ略記セリ.)

\section{第 2 章 霓驗方法}

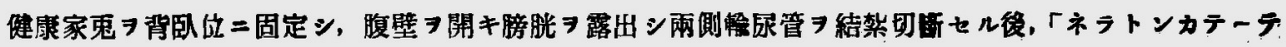

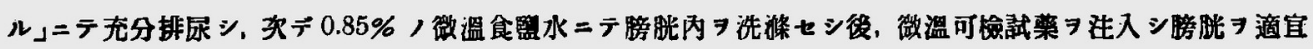

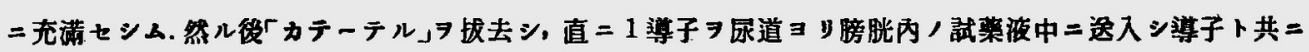

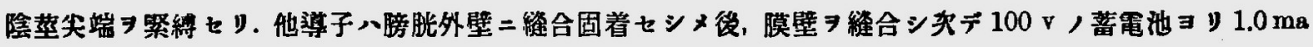

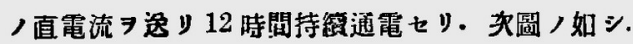

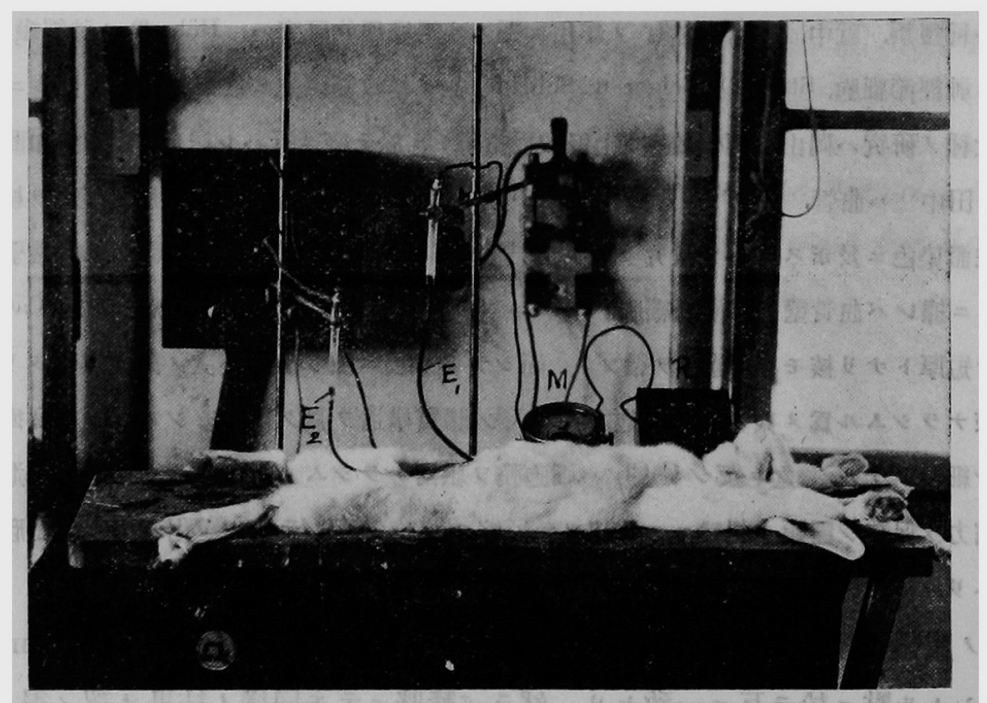

通笔方法

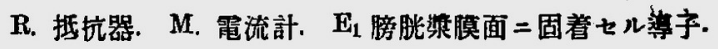

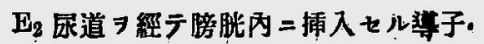




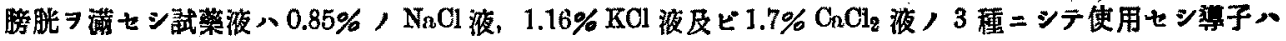

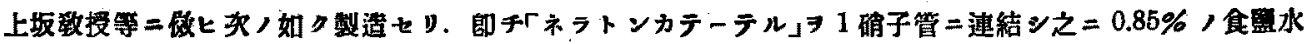

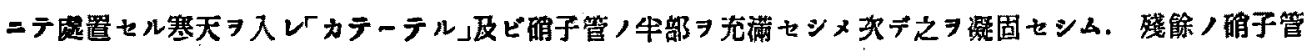

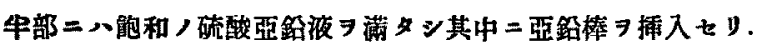

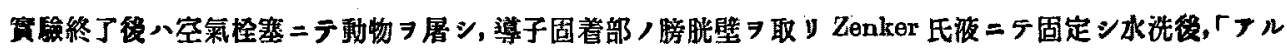

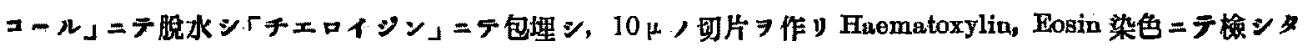
y.

\section{第 3 章 蒀 驗成 綪}

第 1 節 $\quad 0.85 \% \mathrm{NaCl}$ 液 $ᄏ$ 㢁肶二充満シ通電セシモノ

1) 陰樰導子固着部膀㷡壁

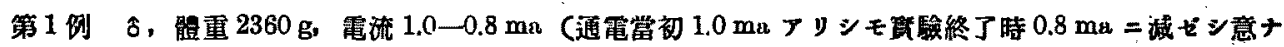
y. 以下之二淮ズ)

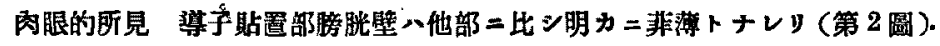

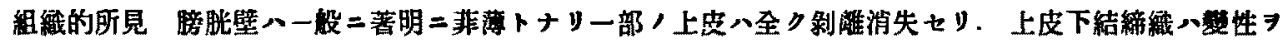

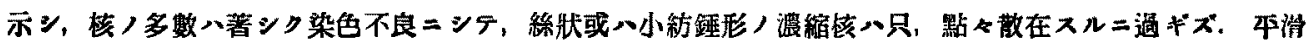

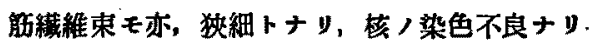

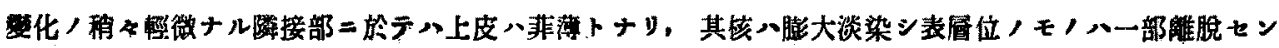

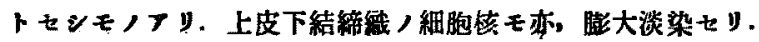

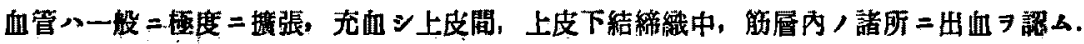

\section{2) 陽極頨子固着部膀腅壁}

第 2 测 $\widehat{o}$, 咀重 $2640 \mathrm{~g}$, 電流 $1.0-0.8 \mathrm{ma}$

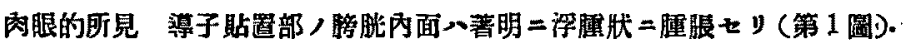

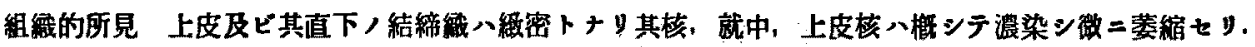

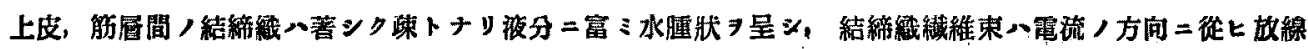

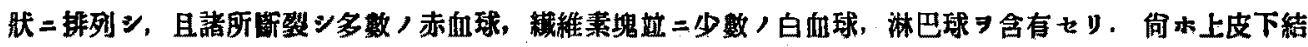

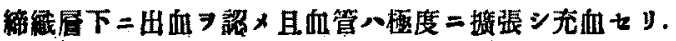

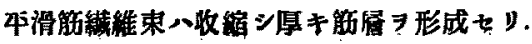

第 2 節 $\quad 1.16 \% \mathrm{KCl}$ 液 $\ni$ 膀胼二充滿シ通電セシモノ

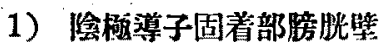

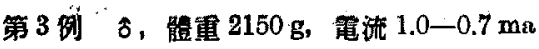

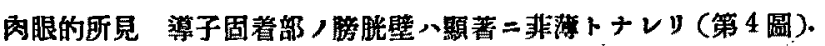

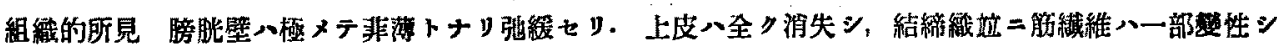

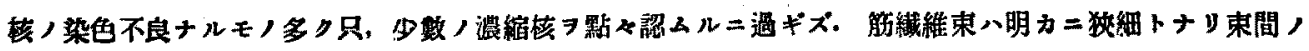




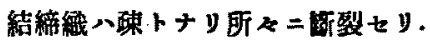

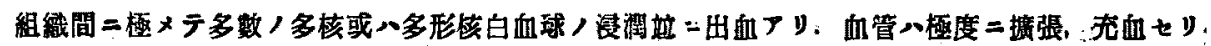

2) 隄極導子固着部膀㷡壁

第 4 例 。，體重 $3130 \mathrm{~g}$ ，電流 $1.0 \mathrm{ma}$

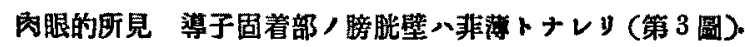

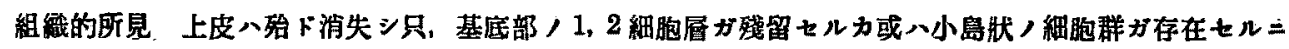

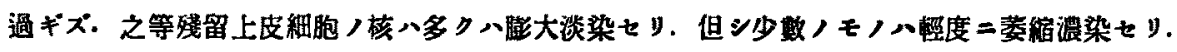

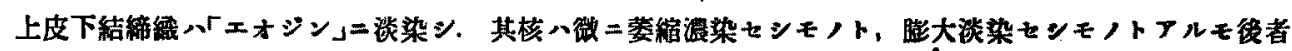
八比䡆的多数ナり.

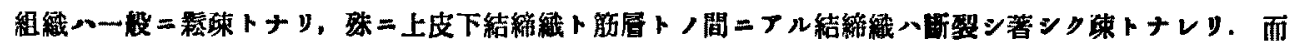
シテ僅二水藏狀 $ヨ$ 呈シ所

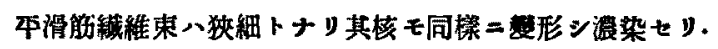

血管ハー一般二著シク充血セり。

第 3 節 $1.7 \% \mathrm{CaCl}_{2}$ 液 $\exists$ 䏽胀二充满シ通電セシモノ

1) 陰樰導子固着部膀胀壁

第 5 例 3 , 體重 $2380 \mathrm{~g}$, 電流 $1.0-0.8 \mathrm{moz}$

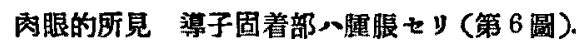

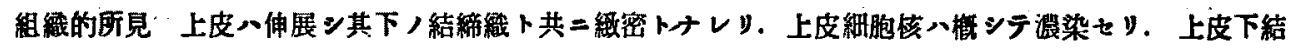

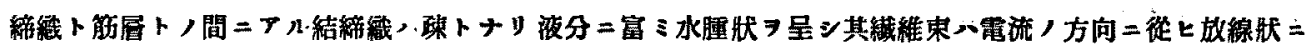

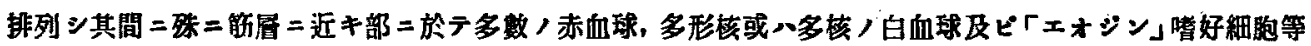
散在性、二淈在七刀。

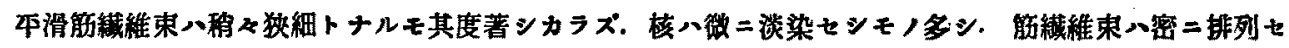
ズンテ其間ノ結締䄉へ䌅䠅トナレリ.

\section{2）陽極導子固着部膀胀䌘}

第 6 例古，體重 $3110 \mathrm{~g}$, 電流 $1.0-0.7 \mathrm{ma}$

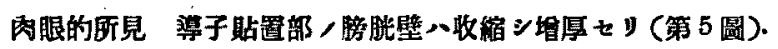

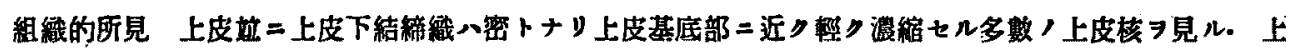

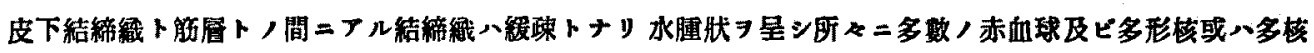
白血球，好「エオシン」白血球二由リテ浸潤セラルルョ見ル。

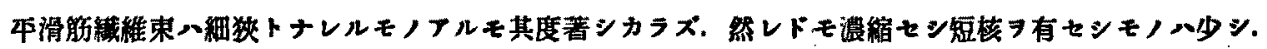

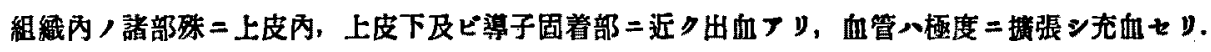

\section{第 4 冓總括站二考按}

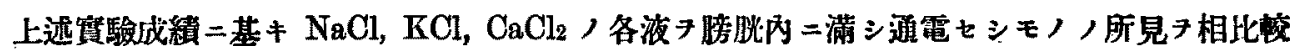


$\pi ル=$,

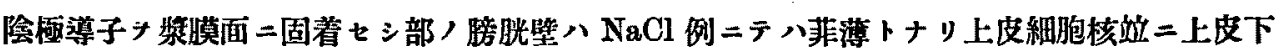

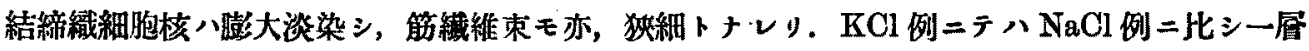

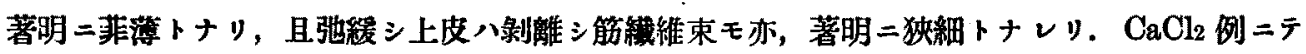
八之二反シ上皮下二水分，㵔溜

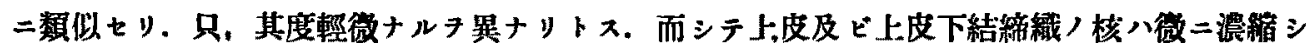

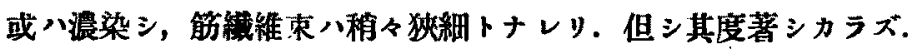

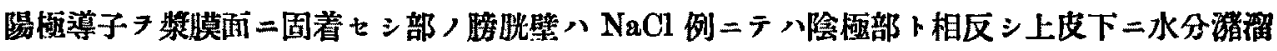

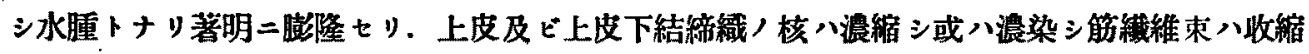

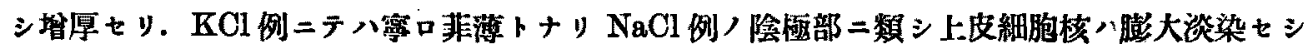
モノ多數ニシテ筇蟣維束ハ明カ二狹細トナレリ． $\mathrm{CaCl}_{2}$ 例ニテハ上皮下二水分潴熘シ水腫狀二

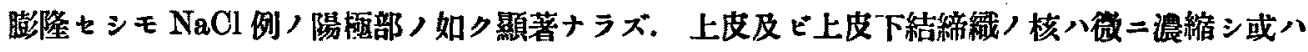
浱染七リ．筋織維束中稍々細狭トナリシモノフルモ多クハ却ッテ收縮セリ．

此各例二於ヶル影著，差暴八如何ナル機轉二基クヤ次二之尹考究セント欲ス.

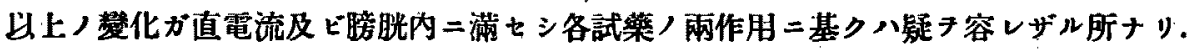

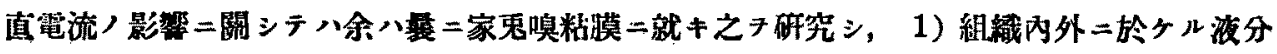

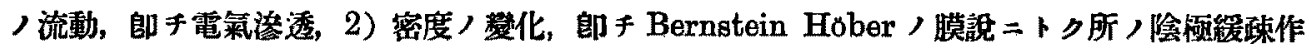
用及ビ陽㥛維密作用二由ツテ變化が起ル旨フ述べタリ。

炏 $=\mathrm{NaCl}, \mathrm{KCl}, \mathrm{CaCl}_{2}$ ，作用二關シテハ $\mathrm{NaCl}$ 八微 $=\mathrm{KCl}$ 八著明二細胞フ䌅柾ナラシメ, $\mathrm{CaCl}_{2}$ ハ却ッテ之キ繳密ナラシム事ハHöber 等ノ整テ述ベミ所ニシテ, 最近上坂较室ノ諸氏二 ヨリ組織的ニモ立證セラレ余モ亦, 咱粘膜ニ於テ之き證明セシ所トス.

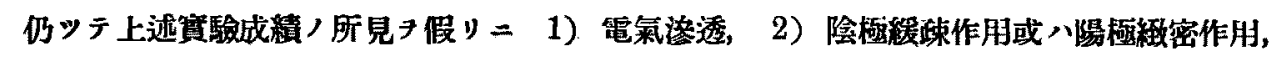

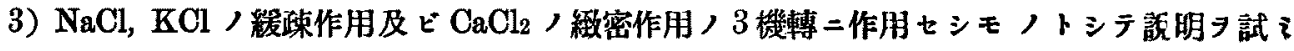
$=$,

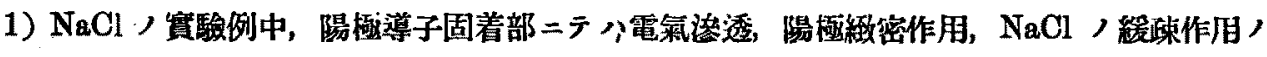

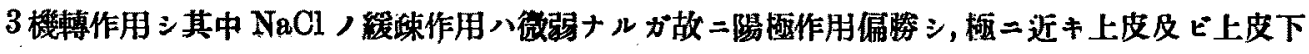

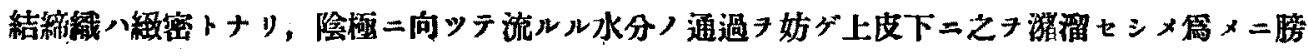

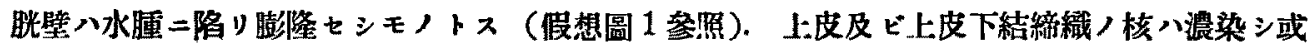
八微二浱縮セシガ是レ陽極維密作用二原因セリ.

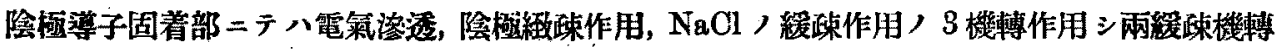

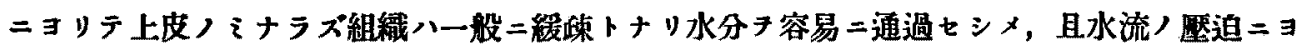
リ壁入菲溥トナリシモノトス（假想圖 2 參照）、上皮及ビ上皮下結締織つ核カ膨大淡染セシハ

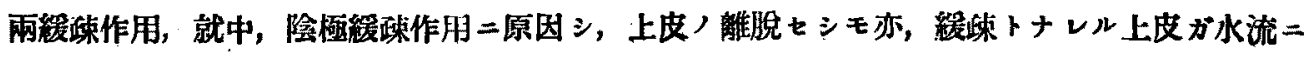


ヨリテ容易二離脫セシニ基キシモ，ト信ズ.

假想圖

1

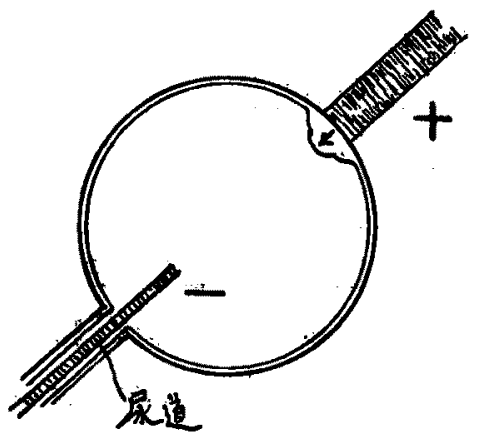

2

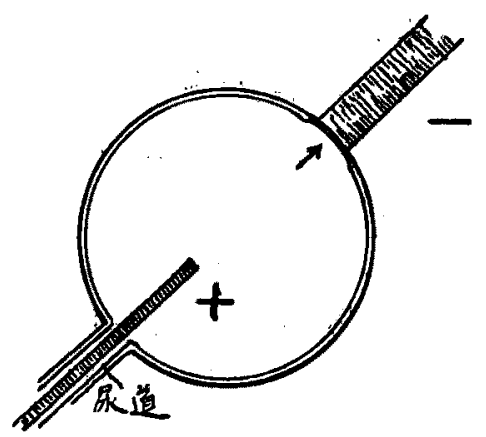

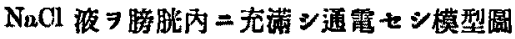

(矢, 方向八水，電橆的流動，方向 7 示ス)

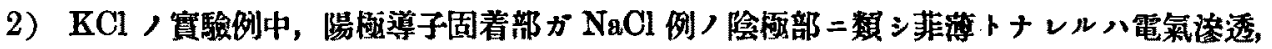

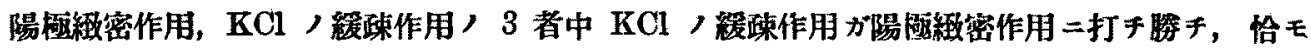

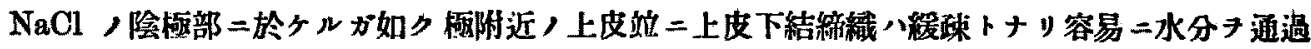

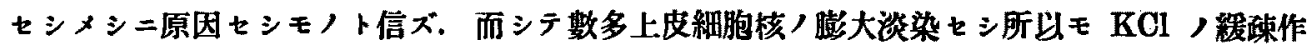
用二基りモノト思考入。

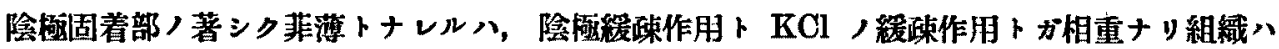

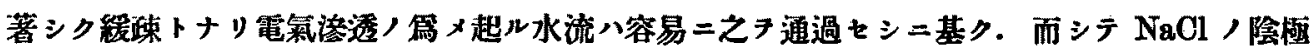

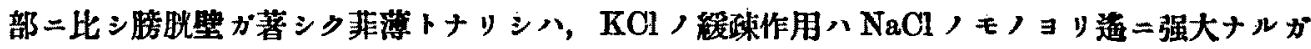
罵メトス。

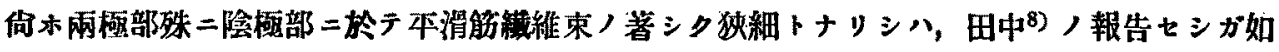

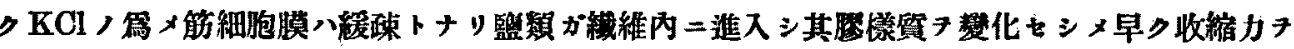

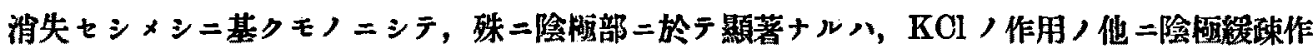

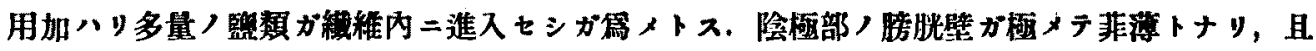

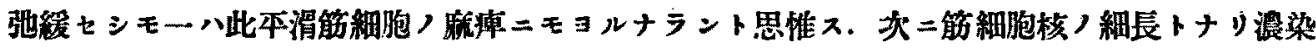
セシ八細胞ノ形態的變化二伴フ續發現象二外ナラズ.

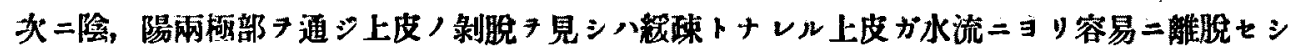
‡ノr.

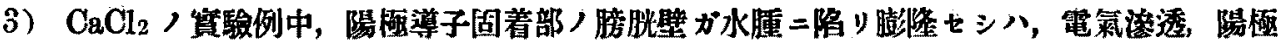

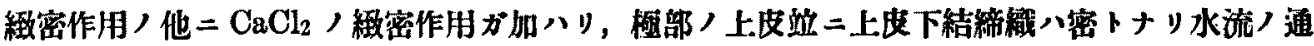




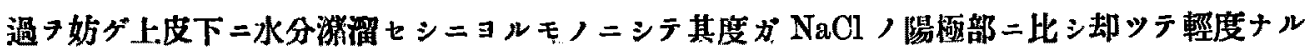

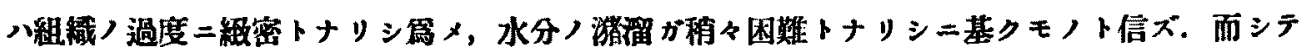

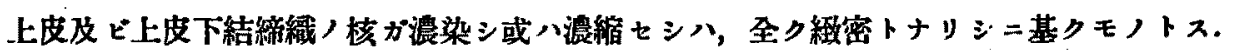

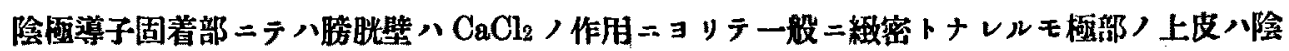

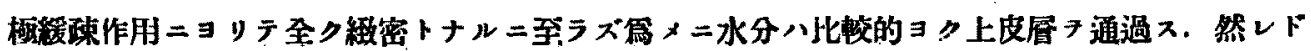

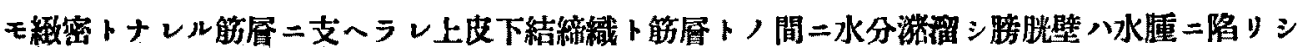
モノトス.

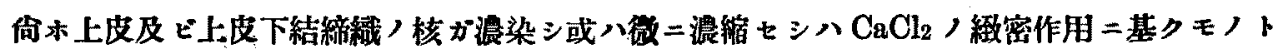
ᄌ.

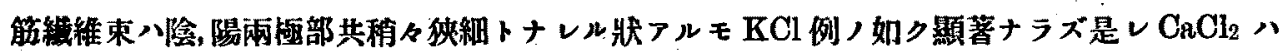

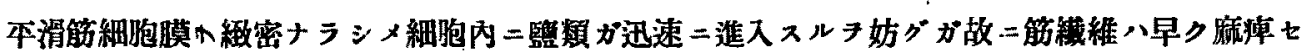

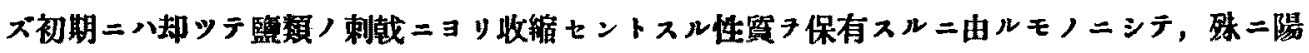

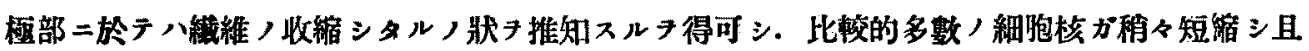

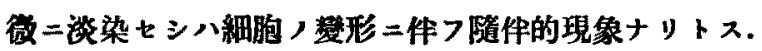

\section{事 5 章結 論}

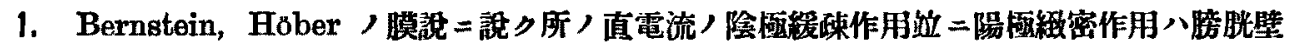
ニテモ磪メ得タリ.

2. $\mathrm{NaCl}, \mathrm{KCl}$ 就中， $\mathrm{KCl}$ ／緩㻋作用及ビ $\mathrm{CaCl}$ ，緻密作用八膀腅暨ニテモ確メ得タリ.

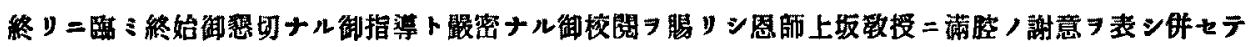

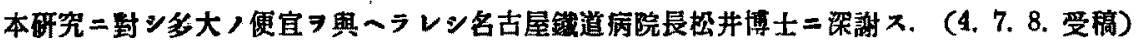

\section{主要引用文路}

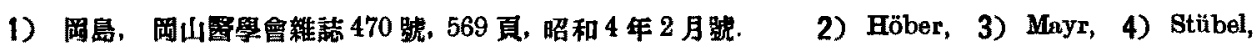

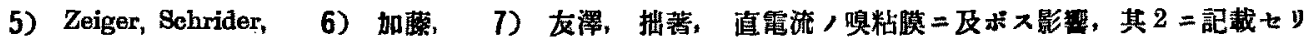

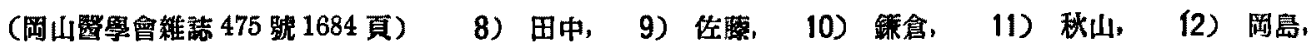

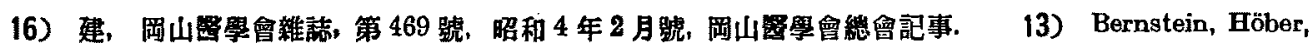

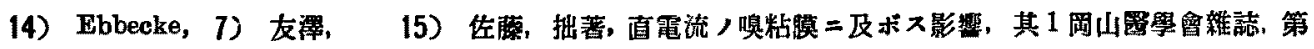

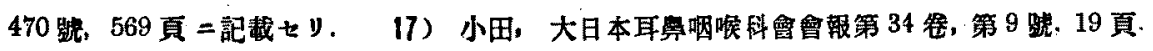




\title{
附圖說明
}

Fig. 1. $0.85 \% \mathrm{NaCl}$ 液 $\Rightarrow$ 膀能內二满シ通電セシ陽

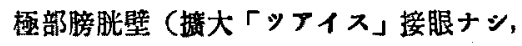
接物燒點 $7.5 \mathrm{~cm}$, 蛇腹長 $57 \mathrm{~cm}$ ) 壁从上皮

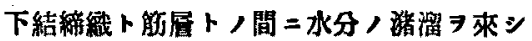
水腱状二胵隆七り。

Fig. 2. 同上 陰極部膀脱壁（搬大同上）壁八菲薄 トナレリ.

Fig. 3. $1.16 \% \mathrm{KCl}$ 液 $\ni$ 膀胱內二满シ通電セシ晹

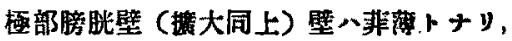
$\mathrm{NaCl}$, 陰楚部 $=$ 類 $ス$.

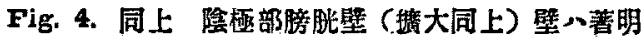

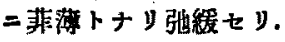

Fig. 5. $1.7 \% \mathrm{CuOl}_{2}$ 液 9 膀胱肉二満シ通電セシ陽

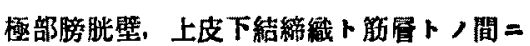
水分，渚溜习來シ水腫习呈シ䐘隆セルを $\mathrm{NnCl}$ 的ノ如り㛲著ナラズ

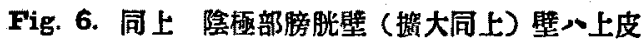
下結綗䄉卜筋層卜，間二水分，售溜 7 來 承䭪习呈シ跀隆セり。

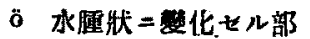

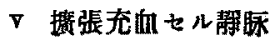

Kurze Inhaltsangabe:

Über den Einfluss des elektrischen

Gleichstromes auf die Blasenwand unter der Mitwirkung von $\mathrm{NaCl}$, $\mathrm{KCl}$ oder $\mathrm{CaCl}_{2}$.

Von

\author{
Kotobu Okajima. \\ Aus dem anatomischen Institut der Universität zu Okknama Japan. \\ (Vorstand : Prof. Dr. K. Kosaka). \\ Eingegangen am 8. Juni 1929.
}

Beim Kaninchen erfüllte der Verf. die Harnblase mit $0.85 \%$-iger NaCl- $1.16 \%$-iger KCl- bezw. $1.7 \%$-iger $\mathrm{CaCl}_{2}$-Lősung und befestigte eine unpolarisierbare Elektrode an ihrer äusseren Fläche, während die andere Elektrode auf dem Wege der Harnröhre in die Blase hineingeführt wurde, um einen Gleichstrom von ca. 1.0 Milliampère aus einer Stromquelle von 100 Volt 12 Stunden lang durch die Blasenwand durchströmen zu lassen. 
岡帛論文附圖

陽 極 部

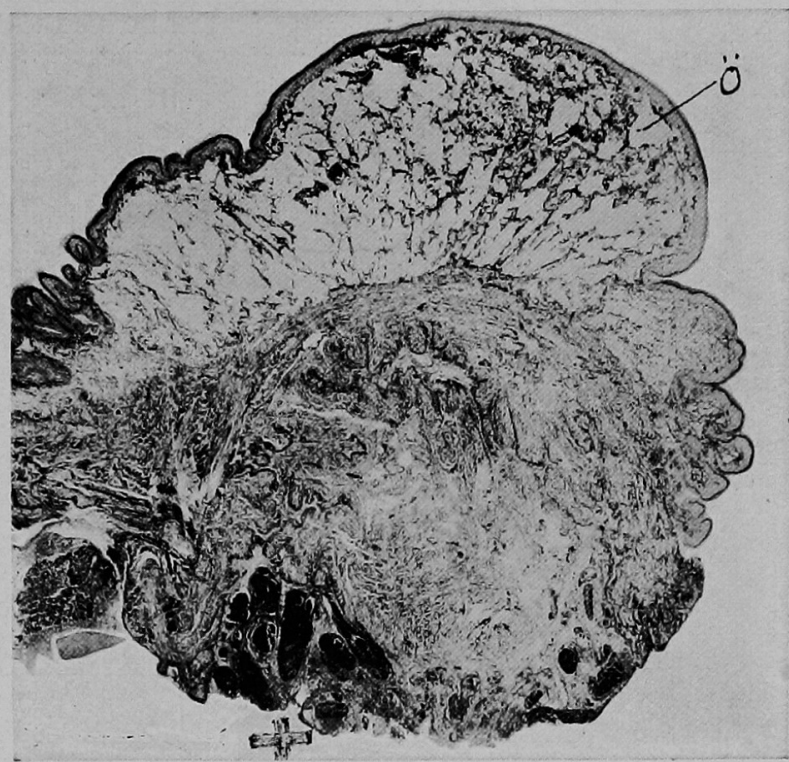

Fig. 1. $\mathrm{NaCl}$

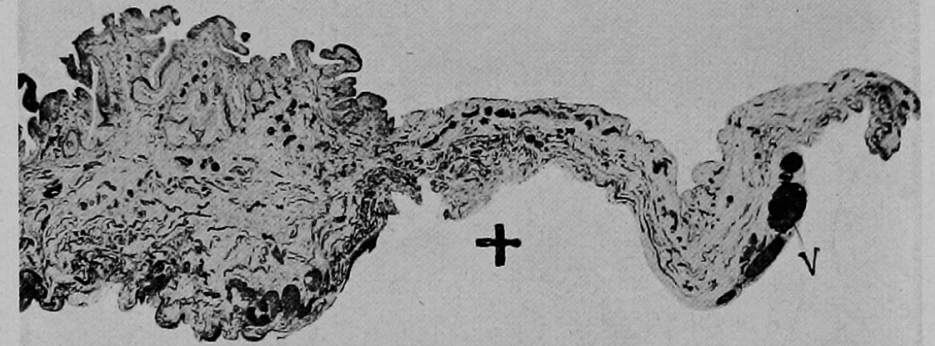

Fig. 3. $\mathrm{KCl}$

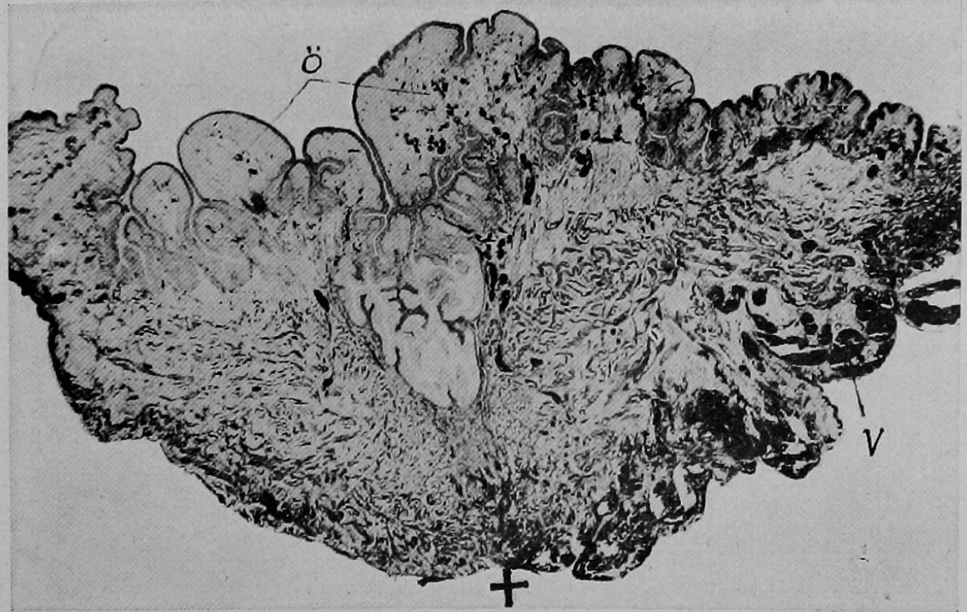

Fig. 5, $\mathrm{CuCl}_{2}$ 


\section{岡島論文附圖}

\section{唡 極 部}

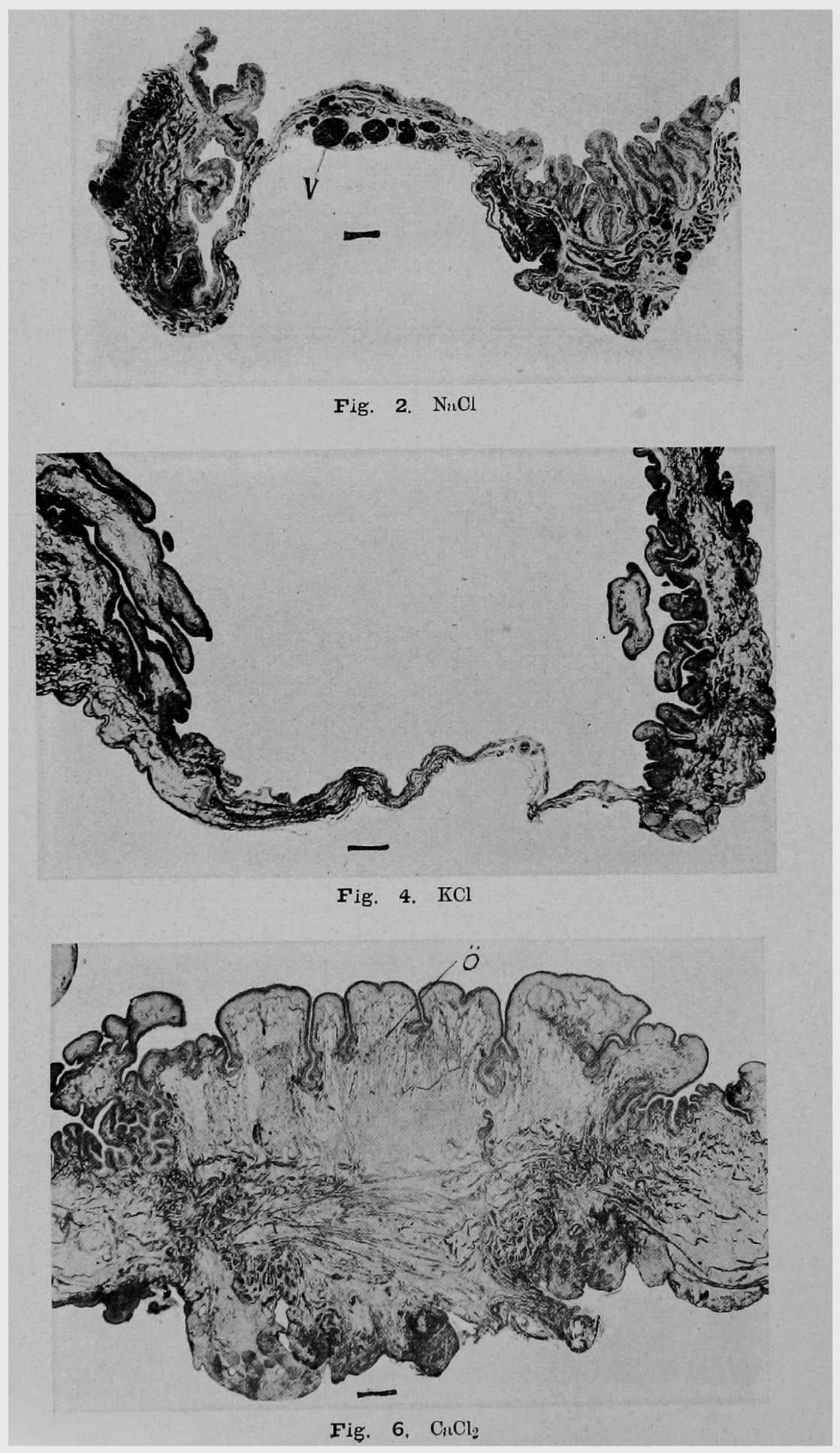


Die histologische Untersuchung der betrefenden Blasenwand ergiebt sich wio folgt.

1) Im Fall von $\mathrm{NaCl}$ zeigt die Blasenwand eine deutliche odematose Anschwellung an der Anode (Fig. 1), indem hier das Epithel und das subepitheliale Bindegewebe sich infolge der Anodenwirkung verdichten und zwischen ihnen und der Muskelschicht Wasser stagnieren lassen.

An der Kathode verhält sich die Sache ganz anders. Die Blasenwand wird hier dünner und das Epithel ist teilweise weggeschaffen (Fig. 2), u. z. deswegen, dass das Gewebe dank der Kathoden- und Salzwirkung viel locker werdend der Elektroendosmose nichts in den Weg legt, und dieser Wasserstrom die Blasenwand bis auf eine dünne Schicht komprimiert und die sich nur locker verbindenden Epithelzellen leicht abspült.

Die Kerne des Epithels und des subepithelialen Bindegewebes sind im Kathodengebiete aufgequollen und lassen sich mit Farbstoffe nur leicht färben, während sie im Anodengebiete mehr oder weniger geschrumpft und intensiver gefärbt sind.

2) Im Fall von $\mathrm{KCl}$ wird die Blasenwand sowohl an der Kathode als auch an der Anode dünner (Fig. 3 u. 4), welch letztere Tatsache darauf zurückzufähren ist, dass die das Gewebe auflockernde Wirkung von $\mathrm{KCl}$ die Anodenwirkung überwiegt. Daher ist der Befund besonders an der Kathode deutlicher, wo auch die Polarwirkung das Gewebe locker macht (Fig. 4).

Die Kerne im Epithel und im subepithelialen Bindegewebe sind im allgemeinen im Anodengebiete aufgequollen und lassen sich mit Farbstoffe schwächer färben. An der Kathode ist das Epithel vollständig verschwunden.

3) Im Fall von $\mathrm{CaCl}_{2}$ zeigt die Blasenwand sowohl im Anoden als auch im Kathodengebiete eine odematóse Anschwellung (Fig. 5 u. 6), wie sie im Anodenabschnitt bei $\mathrm{NaCl}$ der Fall ist, obwohl die Veränderung etwas schwächer zum Vorschein kommt.

Die Kerne des Epithels und des subepithelialen Bindegewebes sind in beiden Abschnitten, besonders aber an der Anode geschrumpft und lassen sich intensiver färben. Hier macht sich vor allem die Wirkung von $\mathrm{CaCl}_{2}$ geltend, indem das Gewebe im allgemeinen dichter wird.

An der Kathode jedoch spielt die Polarwirkung eine entgegengesetzte Rolle, so dras besonders die nicht so dicht werdende Epithelschicht leicht den Wasserstrom zuführt, welcher aber durch die dichte Muskelschicht gehindert zwischen beiden Schichten Wasser stagnieren lässt, (Fig. 6).

Im Anodengebiete wirkt der positive Pol in demselben Sinne mit der Salzwirkung, aber das Gewebe wird dadurch zu dicht und lässt Wasser nicht leicht stagnieren, so dass die Veränderung verhältnismäșsig schwach zutage tritt (Fig. 5), wenn man den Befund mit dem des Anodengebietes im Fall von $\mathrm{NaCl}$ (Fig. 1), vergleicht. 